\title{
The Blood-Brain Barrier in Alzheimer's Disease
}

\author{
Harry V. Vinters and William M. Pardridge
}

\begin{abstract}
The current evidence for and against abnormalities of the blood-brain barrier in "normal" aging and Alzheimer's disease is reviewed. Recent studies of cerebral amyloid angiopathy, a microangiopathy commonly observed in Alzheimer's disease and one suggested to result from blood-brain barrier derangement, are discussed with particular attention to the biochemical nature of the vascular amyloid material, and features it shares with the amyloid found in senile plaque cores and with neurofibrillary tangles. Modern techniques that will probably clarify blood-brain barrier pathophysiology are reviewed.
\end{abstract}

RÉSUMÉ: La barrière hémo-encéphalique dans la maladie d'Alzheimer. Nous revoyons les données actuelles en faveur et contre la présence d'anomalies de la barrière hémo-encéphalique dans la vieillissement normal et dans la maladie d'Alzheimer. Nous analysons des études récentes sur l'angiopathie cérébrale amylö̈de, une micro-angiopathie qu'on observe fréquemment dans la maladie d'Alzheimer et qu'on pense être le résultat d'une anomalie de la barrière hémo-encéphalique. Nous portons une attention particulière dans notre discussion à la constitution biochimique de la substince amyloïde vasculaire et aux particularités communes de cette substance amyloïde et de celle qu'on retrouve dans la partie centrale des plaques séniles et des enchevêtrements neurofibrillaires. Nous faisons une revue des techniques modernes qui permettront probablement d'élucider la pathophysiologie de la barrière hémo-encéphalique.

Can. J. Neurol. Sci. 1986; 13:446-448

The blood-brain barrier (BBB) is constituted by the cerebral capillary and arteriolar (microvascular) endothelium, ${ }^{1-4}$ a highly specialized type of endothelium that modifies and restricts the passage from blood to brain of both large molecules and smaller molecular weight nutrients. ${ }^{5.6}$ Of the numerous theories of etiology and pathogenesis proposed for Alzheimer's disease (AD) and senile dementia of the Alzheimer type (SDAT) over the past few years, only a few have suggested that BBB injury, disruption or abnormality is a key primary event from which all other clinical and pathological hallmarks of the disease evolve. ${ }^{7.8}$ Yet there is reason to believe that BBB abnormalities commonly occur in $A D$, and may contribute to the cognitive deficits as well as to other clinical syndromes in the AD population.

Integrity of the BBB, as measured by several parameters in various animal species, does not seem to become impaired as a simple function of senescence. ${ }^{9.10}$ Similar tracer studies in humans making use of sensitive high molecular weight morphologic tracers (e.g. horseradish peroxidase) and radioisotope labelled compounds (e.g. ${ }^{14} \mathrm{C}$-sucrose) are not feasible. Detailed morphometric assessment of the human BBB (based on surgical biopsy specimens) in non-demented individuals from a range covering the second to the eighth decades of life" has shown the following: capillary walls from the white matter, normally thicker than those in gray matter, undergo progressive thinning until, at advanced age, they are similar in thickness to their grey matter counterparts; $n o$ change in the endothelial mitochondrial population occurs with age, and no alteration in presumed non-specific permeability routes (e.g. endothelial pinocytotic vesicles, junctional gaps) takes place with increasing age. The finding of a loss of pericytes, however, suggests that the BBB in older individuals may less effectively compensate for transient barrier leaks, should these occur." Thus BBB changes are relatively subtle when compared to other age-related morphologic and physiologic phenomena that occur in the human brain. ${ }^{12}$

The situation is different, however, in AD/SDAT. Both direct and indirect evidence suggests that the BBB becomes leaky in this disorder. It remains to be conclusively resolved whether such a functionally abnormal BBB is a cause or an effect of the other brain changes seen in AD. Immunocytochemical studies showing the presence of serum proteins in the neuropil (including senile neuritic plaques) of SDAT brain tissue ${ }^{13}$ imply abnormal BBB permeability during life in these patients. Work employing other methodology, however, suggests that the BBB is intact in $A D$, yet damaged in multi-infarct dementia. ${ }^{14}$ The locus ceruleus, a noradrenergic pontine tegmental nucleus that, through widespread axonal projections appears to exert an

From the Departments of Pathology (Dr. Vinters) and Medicine (Endocrinology) (Dr. Pardridge) and Brain Research Institute (Drs. Vinters and Pardridge), University of California, Los Angeles

Reprint requests to: H.V. Vinters, Dept. of Pathology (Neuropathology), UCLA Medical Center, CHS 18-170, Los Angeles. CA USA 90024 
influence on BBB permeability, ${ }^{15,16}$ becomes depleted of neurons in SDAT ${ }^{17-19}$ though of course this does not prove the existence of a physiological BBB abnormality.

Indirect evidence for BBB abnormalities in AD exists in the common finding of a severe degree of cerebral amyloid angiopathy (CAA) or cerebrovascular amyloidosis in the brains of patients with this type of dementia. ${ }^{20} \mathrm{CAA}$ is a uniquely cerebral microangiopathy characterized by the presence within brain capillary and arteriolar walls of an eosinophilic homogeneous material that shows apple green birefringence when viewed under polarized light - the material is thus a $\beta$-pleated sheet protein. ${ }^{21}$ Ultrastructural study of the amyloid shows it to consist of a random arrangement of nonbranching nonparallel fibrils with a mean diameter on the order of 9-10 $\mathrm{nm}$. The angiopathy clearly involves microvessels of the size that subserve BBB function. Attempts to identify the amyloid material in CAA by immunohistochemistry have yielded conflicting results, but most investigators have agreed on one point: the walls of microvessels affected by CAA as well as the surrounding brain show the presence of serum proteins that reflect abnormal endothelial permeability in the cortex..$^{22-26}$

CAA occurs in the human brain in an age-related fashion, ${ }^{27.28}$ is primarily a neocortical vascular lesion that frequently affects microvessels passing from leptomeninges into cortex, tends to spare deep central grey matter and posterior fossa structures, and can result in massive, sometimes multiple lobar cerebral hemorrhages..$^{20,29-31}$ Many examples of severe CAA are found in patients with $\mathrm{AD}$ - in some studies, over $90 \%$ of $\mathrm{AD}$ brains are affected by CAA. ${ }^{8.32-34}$ CAA, often quite severe, is seen without Alzheimer changes in some brains though the amyloid material has not been chemically characterized in every such case. It is also associated with several other neurodegenerative conditions, some of them familial. ${ }^{20}$ If, as some claim, AD is a hippocampal dementia ${ }^{35}$ it is curious that CAA seems to spare the hippocampal formation. ${ }^{27.33 .36}$ The exact relationship between CAA and amyloid-laden senile plaques in the neocortex is also controversial ${ }^{37}$ (see article, this issue, by Dr. Mary Bell).

Recently, it has become possible to isolate and thus study directly cerebral microvessels affected by CAA. Preparations of amyloid-laden leptomeningeal microvessels from $\mathrm{AD}$ and Down's syndrome brains ${ }^{38-40}$ and parenchymal arterioles from a case of $\mathrm{AD}^{41}$ have now been achieved, allowing for direct biochemical assay of the wall material. All studies show the cerebrovascular amyloid to be a protein with a molecular weight of 4200 daltons and a unique amino acid composition and sequence. Antibodies to a synthetically derived peptide encompassing the first 10 amino acids in this sequence label parenchymalCAA microvessels and the amyloid cores of senile plaques. ${ }^{40}$ CAA amyloid is also similar to peptides isolated directly from the amyloid cores of senile plaques ${ }^{42,43}$ and from purified neurofibrillary tangles ${ }^{44}$ This similarity of the various forms of brain amyloid detected in $\mathrm{AD}$ has led to the hypothesis that $\mathrm{AD}$ is a form of "multiple cerebral amyloidosis" 45,46 and that a circulating amyloid precursor passes from the blood through injured cerebral microvascular endothelium, resulting in vessel wall amyloid deposition (in the form we detect as CAA), and amyloid deposition within the neuropil at the core of many senile plaques. The same theory furthermore proposes that the identical amyloid precursor (perhaps after "processing" by the endothelium) is toxic to neurons and causes the formation of intracytoplasmic neurofibrillary tangles. Another possibility is that the 'amyloidogenic' precursor toxic to neurons results in neuritic degeneration and secondary amyloid deposition within the resultant plaques. The unique propensity of the cerebral and not visceral microvasculature to develop amyloid angiopathy is explained by the characteristic features (and probably distinctive proteolytic enzyme complement) of micovascular endothelium within the CNS. This model fails to specify whether BBB injury is a cause or a result of CAA or what the endothelial "processing" abnormality may be, and other investigators claim that neurofibrillary tangles, senile plaque core amyloid, and CAA all originate within the brain parenchyma. ${ }^{44}$

Whatever is the ultimate resolution of these crucial research questions, studies on the BBB in AD/SDAT and other disorders, are likely to retain the limelight for some time. They are facilitated by the fact that the key component of the BBB, viable cerebral capillaries and arterioles, can be isolated from the brain with relative ease. This has been accomplished with several animal species and, more recently, with human brain obtained at postmortem examination. ${ }^{47-49}$ Furthermore, cerebral capillary endothelium from several sources, including human brain, ${ }^{50}$ can be cultured, allowing for studies based on an artificially reconstructed $\mathrm{BBB}$ in vitro. ${ }^{51,52}$ This new technology is certain to clarify many of the confusing ideas that have arisen about the BBB, its role in normal brain function and in disease states that affect the CNS.

\section{ACKNOWLEDGEMENTS}

Secretarial assistance provided by Scott Brooks. H.V.V. supported by UCLA Biomedical Research Support Grant.

\section{REFERENCES}

1. Reese TS, Karnovsky MJ. Fine structural localization of a bloodbrain barrier to exogenous peroxidase. J Cell Biol 1967; 34: 207.217.

2. Bradbury $M W B$. The structure and function of the blood-brain barrier. Fed Proc 1984; 43: 186-190.

3. Conford EM. The blood-brain barrier, a dynamic regulatory interface. Molec Physiol 1985; 7: 219-260.

4. Petito CK, Levy DE. The importance of cerebral arterioles in alterations of the blood-brain barrier. Lab Invest 1980;43:262-268.

5. Pardridge WM. Transport of nutrients and hormones through the blood-brain barrier. Fed Proc 1984; 43: 201-204.

6. Pardridge WM. Brain metabolism: a perspective from the bloodbrain barrier. Physiol Rev 1983; 63: 1481-1535.

7. Glenner GG. Congophilic microangiopathy in the pathogenesis of Alzheimer's syndrome (presenile dementia). Med Hypotheses 1979; 5: 1231-1236.

8. Glenner GG. On causative theories in Alzheimer's disease. Hum Pathol 1985; 16: 433-435.

9. Rudick RA, Buell SJ. Integrity of blood-brain barrier to peroxidase in senescent mice. Neurobiol Aging 1983; 4: 283-287.

10. Rapoport SI, Ohno K, Pettigrew KD. Blood-brain barrier permeability in senescent rats. J Gerontol 1979; 34: 162-169.

11. Stewart PA, Magliocco M, Hayakawa K, et al. A quantitative analysis of blood-brain barrier ultrastructure in the aging human. Microvasc Res 1986; (in press).

12. Creasey H, Rapoport SI. The aging human brain. Ann Neurol 1985; 17: 2-10.

13. Wisniewski HM, Kozlowski PB. Evidence for blood-brain barrier changes in senile dementia of the Alzheimer type (SDAT). Ann NY Acad Sci 1982; 396: 119-129.

14. Leonardi A, Gandolfo C, Caponnetto C, et al. The integrity of the blood-brain barrier in Alzheimer's type and multi-infarct dementia evaluated by the study of albumin and $\operatorname{IgG}$ in serum and cerebrospinal fluid. J Neurol Sci 1985; 67: 253-261. 
15. Raichle ME, Hartman BK, Eichling JO, et al. Central noradrenergic regulation of cerebral blood flow and vascular permeability Proc Natl Acad Sci USA 1975; 72: 3726-3730.

16. Harik SI, McGunigal T Jr. The protective influence of the locus ceruleus on the blood-brain barrier. Ann Neurol 1984; 15: 568-574.

17. Lockhart MP, Gibson CJ, Ball MJ. Topographical loss of locus coeruleus cells in Alzheimer's disease. Neuroscience Abstracts 1984; 10: 995.

18. Tomlinson BE, Irving D, Blessed G. Cell loss in the locus coeruleus in senile dementia of Alzheimer type. J Neurol Sci 1981; 49: 419-428.

19. Bondareff W, Mountjoy CQ, Roth M. Loss of neurons of origin of the adrenergic projection to cerebral cortex (nucleus locus ceruleus) in senile dementia. Neurology 1982; 32: 164-168.

20. Vinters HV. Cerebral amyloid angiopathy - a critical review. Stroke 1986; (in press).

21. Richardson EP Jr. Amyloid in the human brain. West J Med 1985; 143: 518-519.

22. Torack RM, Lynch RG. Cytochemistry of brain amyloid in adult dementia. Acta Neuropathol (Berl) 1981; 53: 189-196.

23. Probst A, Heitz PhU, Ulrich J. Histochemical analysis of senile plaque amyloid and amyloid angiopathy. Virchows Arch [A] 1980; 388: 327-334.

24. Eikelenboom P, Stam FC. An immunohistochemical study on cerebral vascular and senile plaque amyloid in Alzheimer's dementia. Virchows Arch [Cell Pathol] 1984; 47: 17-25.

25. Powers JM, Schlaepfer WW, Willingham MC, et al. An immunoperoxidase study of senile cerebral amyloidosis with pathogenetic considerations. J Neuropathol Exp Neurol 1981; 40:592-612.

26. Goust J-M, Mangum M, Powers JM. An immunologic assessment of brain-associated IgG in senile cerebral amyloidosis. J Neuropathol Exp Neurol 1984; 43: 481-488.

27. Vinters HV, Gilbert JJ. Cerebral amyloid angiopathy: incidence and complications in the aging brain. II. The distribution of amyloid vascular changes. Stroke 1983; 14: 924-928.

28. Tomonaga $M$. Cerebral amyloid angiopathy in the elderly. J Am Geriatr Soc 1981; 29: 151-157.

29. Gilbert JJ, Vinters HV. Cerebral amyloid angiopathy: incidence and complications in the aging brain. I. Cerebral hemorrhage. Stroke 1983; 14: 915-923.

30. Okazaki H, Reagan TJ, Campbell RJ. Clinicopathologic studies of primary cerebral amyloid angiopathy. Mayo Clin Proc 1979; 54 : 22-31.

31. Gilles C, Brucher JM, Khoubesserian P, et al. Cerebral amyloid angiopathy as a cause of multiple intracerebral hemorrhages. Neurology 1984; 34: 730-735.

32. Glenner GG, Henry JH, Fujihara S. Congophilic angiopathy in the pathogenesis of Alzheimer's degeneration. Ann Pathol 1981; 1: 120-129.

33. Mlandybur TI. The incidence of cerebral amyloid angiopathy in Alzheimer's disease. Neurology 1975; 25: 120-126.

34. Ranalli P, Bergeron C. Amyloid angiopathy in Alzheimer's disease.
Ann Neurol 1984; 16: 119.

35. Ball MJ, Hachinski V, Fox A, et al. A new definition of Alzheimer's disease: a hippocampal dementia. Lancet 1985; I: 14-16.

36. Morimatsu M, Hirai S, Muramatsu A, et al. Senile degenerative brain lesions and dementia. J Am Geriatr Soc 1975; 23: 390-406.

37. Mountjoy CQ, Tomlinson BE, Gibson PH. Amyloid and senile plaques and cerebral blood vessels. A semi-quantitative investigation of a possible relationship. J Neurol Sci 1982; 57: 89-103.

38. Glenner GG, Wong CW. Alzheimer's disease: initial report of the purification and characterization of a novel cerebrovascular amyloid protein. Biochem Biophys Res Comm 1984; 120: 885-890.

39. Idem. A eimer's disease and Down's syndrome: sharing of a unique cerebrovascular amyloid fibril protein. Biochem Biophys Res Comm 1984; 122: 1131-1135.

40. Wong CW, Quaranta V, Glenner GG. Neuritic plaques and cerebrovascular amyloid in Alzheimer disease are antigenically related. Proc Natl Acad Sci USA 1985; 82: 8729-8732.

41. Pardridge WM, Vinters HV, Yang J, et al. Amyloid angiopathy of Alzheimer's disease: amino acid composition of a $\mathbf{4 2 0 0}$ dalton peptide isolated from cortical microvessels. 1986, (submitted).

42. Masters CL, Simms G, Weinman NA, et al. Amyloid plaque core protein in Alzheimer's disease and Down syndrome. Proc Natl Acad Sci USA 1985; 82: 4245-4249.

43. Allsop D, Landon $M$, Kidd $M$. The isolation and amino acid composition of senile plaque core protein. Brain Res 1983;259: 348-352.

44. Masters CL, Multhaup G, Simms G, et al. Neuronal origin of a cerebral amyloid: neurofibrillary tangles of Alzheimer's disease contain the same protein as the amyloid of plaque cores and blood vessels. EMBO J 1985; 4: 2757-2763.

45. Glenner GG. Alzheimer's disease. The commonest form of amyloidosis. Arch Pathol Lab Med 1983; 107: 281-282.

46. Glenner GG. Alzheimer's disease: multiple cerebral amyloidosis. In: Banbury Report 15: Biological aspects of Alzheimer's disease. Cold Spring Harbor, New York: Cold Spring Harbor Laboratory, 1983: 137-144.

47. Pardridge WM, Eisenberg J, Yang J. Human blood-brain barrier insulin receptor. J Neurochem 1985; 44: 1771-1778.

48. Choi T, Pardridge WM. Phenylalanine transport at the human blood-brain barrier. Studies with isolated human brain capillaries. J Biol Chem 1986; 261: 6536-6541.

49. Jo6 $\mathrm{F}$. The blood-brain barrier in vitro: ten years of research on microvessels isolated from the brain. Neurochem Int. 1985; 7 : $1-25$.

50. Vinters HV, Reave S, Costello P, et al. Isolation and culture of cells derived from human cerebral microvessels. J Neuropathol Exp Neurol 1985; 44: 338.

51. Beck DW, Vinters HV, Hart MN, Cancilla PA. Glial cells influence polarity of the blood-brain barrier. I Neuropathol Exp Neurol 1984; 43: 219-224.

52. Bowman PD, Ennis SR, Rarey KE, et al. Brain microvessel endothelial cells in tissue culture: a model for study of blood-brain barrier permeability. Ann Neurol 1983; 14: 396-402. 